Available online on 15.09.2020 at http://ujpr.org
Universal Journal of Pharmaceutical Research
An International Peer Reviewed Journal
Open access to Pharmaceutical research is an open access article distributed under the terms of the Creative Commons Attribution-Non
Commercial Share Alike 4.0 License which permits unrestricted non commercial use,
provided the original work is properly cited
Volume 5, Issue 4, 2020

\title{
VULVOVAGINAL CANDIDIASIS PREVALENCE AMONG PREGNANT WOMEN IN DIFFERENT HOSPITALS IN IBB, YEMEN Wadhah Hassan Edrees ${ }^{1,2 *}{ }^{\infty}$, Amin Abdo Al-Asbahi ${ }^{3}{ }^{\circledR}$, Wadee Abdullah Al-Shehari ${ }^{4}{ }^{\oplus}$, Eglal Ahmed Qasem ${ }^{4}$ (B) \\ ${ }^{I}$ Medical Laboratory Department, Faculty of Medical Sciences, Al-Razi University, Yemen. \\ ${ }^{2}$ Medical Microbiology Department, Faculty of Applied Sciences, Hajjah University, Yemen. \\ ${ }^{3}$ Medical Laboratory Department, Faculty of Medicine and Health Sciences, Amran University. ${ }^{4}$ Department of Microbiology, Faculty of Medical Sciences, Ibb University, Yemen.
}

\section{ABSTRACT}

Background and aims: Candida species are opportunistic yeasts that affect the genital urinary tract that causes vulvovaginal candidiasis in the most females, particularly in developing countries. This work aims to find the prevalence of vulvovaginal candidiasis among pregnant women in Ibb, Yemen.

Material and methods: Two hundred and eighteen samples of females attending outpatient obstetrics and gynecology clinics were chosen from several hospitals (Al-Thawra, Maternity and Childhood Center, Maternal Reproductive Health Center, and Nasser General Hospital) located in Ibb, from December 2019 to March 2020. The laboratory works were performed in the microbiology department of Al-Thawra Hospital, Ibb. Vaginal swabs were cultivated on Sabouraud dextrose agar, then the species of Candida identification and anti-fungal sensitivity tests were performed regarding the standard procedure of microbiology.

Results: The findings revealed that out of 218 cases, 134 (61.5\%) were infected with Candida species, and the rate of candidiasis was higher among women coming from rural areas than among women in urban areas; and in the age group 28-37 years. $C$. albicans $(61.2 \%)$ were the most prevalent species followed by C. tropicalis (21.64\%), C. glabrata (11.19\%), and C. kefyr (5.97\%). Susceptibility tests showed that the most isolated Candida species were sensitive to nystatin (94.8), fluconazole (91.04\%), amphotericin B $(88.80 \%)$, voriconazole $(78.35 \%)$, clotrimazole $(75.37 \%)$, ketoconazole $(73.13 \%)$, and itraconazole $(69.40 \%)$. Conclusion: It can be concluded that Candida vaginitis is very common among pregnant women, and the tested anti-fungal agents continue to be effective against all isolates of Candida species. In contrast, there was a slight increase resistant against itraconazole, ketoconazole, clotrimazole, and voriconazole which raises concern about a rise in Candida species that are resistant to these drugs.

Keywords: Candida albicans, Susceptibility antifungal, Vulvovaginal candidiasis (VVC), Yemen.

Article Info: Received 27 June 2020; Revised 15 July; Accepted 12 August, Available online 15 September 2020
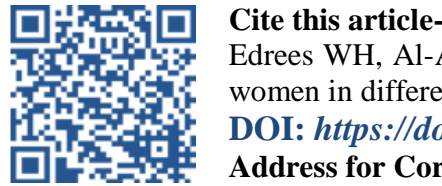

Edrees WH, Al-Asbahi AA, Al-Shehari WA, Qasem EA. Vulvovaginal candidiasis prevalence among pregnant women in different hospitals in Ibb, Yemen. Universal Journal of Pharmaceutical Research 2020; 5(4):1-5.

DOI: https://doi.org/10.22270/ujpr.v5i4.431

Address for Correspondence

Dr. Wadhah Hassan Edrees, Medical Laboratory Department, Faculty of Medical Sciences, Al-Razi University, Yemen, Tel: +967-771673230, E-mail: edress2020@gmail.com

\section{INTRODUCTION}

Candida vaginitis, also often called vulvovaginal candidiasis, is a pathogen of the vagina caused by diverse types of Candida species ${ }^{1,2}$. Vulvovaginal candidiasis (VVC) considers the second disease cause of symptomatic vaginal diseases after bacterial vaginitis ${ }^{1,3}$ and responsible for over $25 \%$ of infectious vaginitis $^{4,5}$. Almost $75 \%$ of women have VVC in their lifetime ${ }^{3}$. Also, it was documented that more than $40 \%$ of affected females will have two or more incidence of vulvovaginal candidiasis in the year ${ }^{6,7}$. The clinical manifestations of vulvovaginal candidiasis are representing on the itching, vaginal discomfort, an unpleasant burning feeling, and soreness that lead to whitish-yellowish vaginal discharge often with a curdlike appearance ${ }^{8}$. The frequency rates of Candida species among pregnant women with VVC various from the study area to another' ${ }^{9}$. Some reports have documented that the $C$. albicans was ranged between $80-90 \%$ among women with acute VVC that caused by Candida sp., whereas other species of Candida are less frequently isolated ${ }^{1,10,11}$. However, in the last 10 years, there are different species of non-albicans Candida that are C. parapsilosis, C. glabrata, C. krusei, $C$. 
lusitaniae, C. tropicalis, C. dubliniensis, and $C$. guilliermondii isolated from vaginal samples ${ }^{12,13,14}$. Misuse of antifungal drugs and lack of effective policies that control the use of antifungal, especially against the vulvovaginal candidiasis lead to increase resistance of Candida species to several antifungal drugs $^{15}$. There are limited reports that documented the prevalence of vaginitis in Yemen. A study by AL-Haik and $\mathrm{Al}$-Haddad ${ }^{16}$ reported that $39.2 \%$ of pregnant women have been infected with bacterial vaginosis in Hadhramout city. While there have been several studies that discussed oral candidiasis in Yemen in the past five years ${ }^{17,18,19}$.

A study, in Sana'a, by Abdul-Aziz et al., ${ }^{20}$ found that the frequency of vaginal infection among reproductiveaged women was $37.6 \%$ of collecting samples. Also, the results showed that $27.2 \%$ by bacterial vaginosis, $6.6 \%$ by vulvovaginal candidiasis, and $0.9 \%$ by trichomonal vaginosis. To date, data on the prevalence of vulvovaginal candidiasis among women during pregnancy period and the rate of resistance to antifungal drugs for Candida species are not available for the city of Ibb, Yemen. So, the present study aimed to find the prevalence and types of Candida that cause vulvovaginal candidiasis among pregnant women and their sensitivity to antifungal drugs in Ibb, Yemen.

\section{MATERIALS AND METHODS}

Study Design and Data Collection

Two hundred and eighteen (218) samples were sampled from pregnant women presenting Obstetrics and Gynecology outpatient clinics in several hospitals (AL-Thwrah, Maternity Center and Childhood, Reproductive Health Center for Mothers, Nasser General hospital) that situated in Ibb City, in the period from December 2019 to March 2020. All participated cases were interviewed and patient information was reported with intended questionnaires that include; demographic, age, medical history, and symptoms.

\section{Sample Collection}

The swab specimens were collected from female pregnant by the obstetrician. By using s sterile cotton swab, two wipes per patient, was carefully inserted into the upper part of the vagina. The samples were immediately transmitted to the diagnostic laboratory of the Microbiology Department of the AL-Thwrah Hospital for examination ${ }^{3,21}$.

\section{Examination of Specimen}

Microscopic Examination

One swab of each case was subjected to direct examination by the wet mount. One drop of normal saline was transferred to each sample and mixed well and microscopically examined under $10 \mathrm{x}$ and $40 \mathrm{x}^{22}$.

\section{Culture Methods}

The second swab was cultivated on the surface of Sabouraud Dextrose Agar (SDA) (Oxide, UK) with chloramphenicol $(250 \mathrm{mg} / \mathrm{l})$. The plates were incubated for $48 \mathrm{~h}$ at $37^{\circ} \mathrm{C}$. The morphological features for the colony were studied and confirmed by detecting the budding characterization with pseudo-hyphae by using the Gram tube test ${ }^{23}$.

\section{Candida species Identification}

The Candida species were identified according to morphological characterizations on the surface of culture medium, the formation of germ tube test, and carbohydrate assimilation as the following:

\section{Germ Tube Test}

A small part from a pure colony of Candida species was picked and transported into a sterile tube that contains $0.5 \mathrm{ml}$ serum of human, mixed well, and aerobic incubated for $2 \mathrm{~h}$ at $37^{\circ} \mathrm{C}$. Then, one drop of each serum was transported to a clean slide and scanned by a microscope with objective lenses $(x 40)$ to identify the existence of germ tubes that characterized with initially short hyphal ${ }^{24}$.

\section{Sugar Assimilation Test}

From the overnight of yeast suspension culture, one $\mathrm{mL}$ was transferred to the basal carbohydrate-free medium (II) of molten agar cooled to $45^{\circ} \mathrm{C}$ and poured to petri dish plates. Saturated discs with $1 \%$ with sugar were placed on the solidified surface of plates and incubated for five days at $37^{\circ} \mathrm{C}$. The occurrence of growth around each disc implies the carbohydrate assimilation of tested sugar. The glucose, sucrose, Dgalactose, maltose, raffinose, lactose, trehalose, and xylose were used in the sugar assimilation test ${ }^{25}$.

\section{Antifungal Susceptibility Testing}

The isolated Candida species were subjected to susceptibility antifungal agents by using a disc diffusion technique on the surface of Mueller Hinton agar. The used antifungal discs were Nystatin $(100 \mu \mathrm{g})$, Clotrimazole $(50 \mu \mathrm{g})$, Itraconazole $(50 \mu \mathrm{g})$, Ketoconazole $(10 \mathrm{mg})$, Voriconazole $(10 \mu \mathrm{g})$, Amphoteracin B $(50 \mu \mathrm{g})$, and Fluconazole $(100 \mu \mathrm{g})$ (Himedia, India). The inhibition zone was measured after $48 \mathrm{~h}$ of incubation at $37^{\circ} \mathrm{C}^{26}$.

\section{RESULTS}

A hundred and thirty-four samples (61.5\%) found positive growth in culture and 84 specimens $(38.5 \%)$ recorded negative growth (Figure 1). Table 1 shows the prevalence of vulvovaginal candidiasis regarding patient's residents. It was observed that the women coming from the rural area had the highest rate $(65 \%)$ while the patients coming from the urban area was $60.13 \%$.

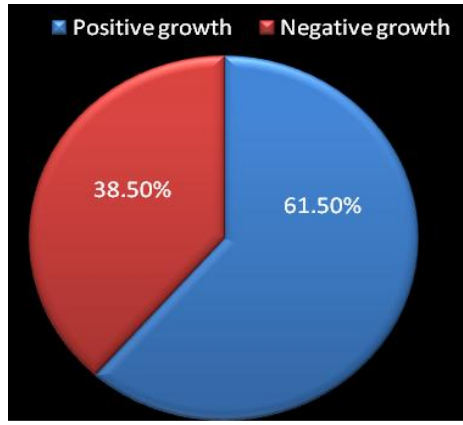

Figure 1: The type of growth in culture media.

However, this work revealed that the highest rate of infection for first-time was $96 / 165(58.18 \%)$, while the recurrent infection was 38/53 (71.69\%). Table 2 shows that the highest prevalence of Candida infection was $73(54.48 \%)$ recorded in the group aged 28-37 years 
and followed by a group aged between 38-47 years 49 $(36.57 \%)$. While the lower rate of Candida infection was reported in the age group of $18-27$ years $12(8.95 \%)$.

Table 1: Rate of candidiasis infection regard to resident.

\begin{tabular}{llll}
\hline $\begin{array}{l}\text { Residence } \\
\text { area }\end{array}$ & $\begin{array}{l}\text { No. of } \\
\text { examined }\end{array}$ & $\begin{array}{l}\text { Positive } \\
(\%)\end{array}$ & $\begin{array}{l}\text { Negative } \\
(\%)\end{array}$ \\
\hline Urban & 158 & $95(60.13)$ & $63(39.87)$ \\
Rural & 60 & $39(65)$ & $21(35)$ \\
Total & 218 & $134(61.5)$ & $84(38.5)$ \\
\hline
\end{tabular}

The current study found that $96(71.64 \%)$ of cases were reported as the first time infected with vulvovaginal candidiasis, while $38(28.36 \%)$ of cases were recorded as the recurrent vulvovaginal candidiasis (Figure 2).

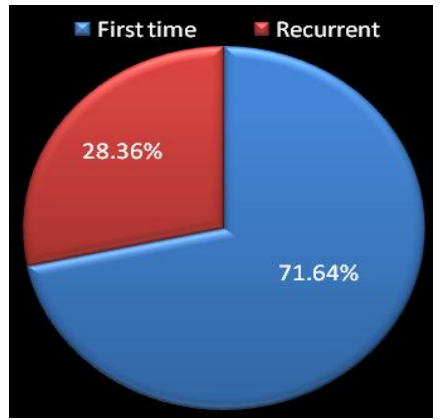

Figure 2: The first time and recurrent infection.

In the present investigation, it was isolated four species of Candida from vaginal specimens and identified according to carbohydrate assimilation. C. albicans was $(61.2 \%)$ the most predominant Candida species identified from specimens followed by an non-albicans species that are C. tropicalis 29(21.64\%), C. glabrata $15(11.19 \%)$, and C. kefyr 8(5.97\%) (Figure 3$)$.

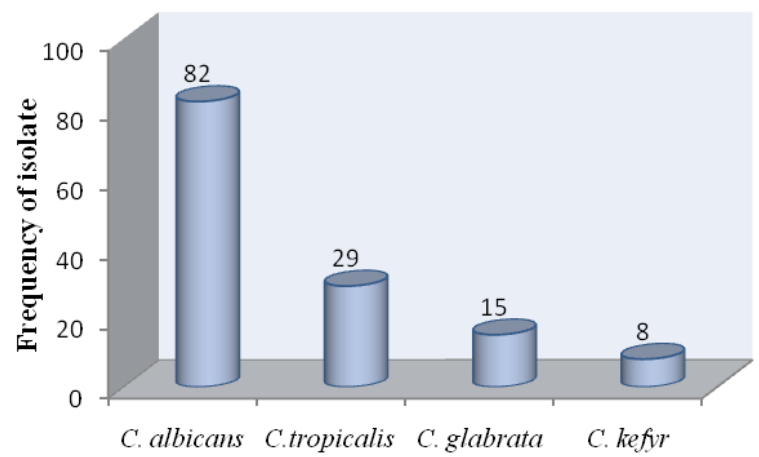

Figure 3: Distribution of isolated Candida species from pregnant .

Table 2: Prevalence of vulvovaginal candidiasis related to age.

\begin{tabular}{ccc}
\hline $\begin{array}{c}\text { Age in } \\
\text { years }\end{array}$ & $\begin{array}{c}\text { Examined } \\
\text { No. }(\%)\end{array}$ & $\begin{array}{c}\text { Positive Candida } \\
\text { sp. No. }(\%)\end{array}$ \\
\hline $18-27$ & $35(16.1)$ & $12(8.95)$ \\
$28-37$ & $122(55.96)$ & $73(54.48)$ \\
$38-47$ & $61(27.98)$ & $49(36.57)$ \\
Total & $218(100)$ & $134(100)$ \\
\hline
\end{tabular}

The susceptibility results revealed that $94.8 \%$ of identified Candida species were sensitive to nystatin. Fluconazole was the second drug with $91.04 \%$ susceptible followed by amphotericin B (88.8\%), voriconazole $(78.35 \%)$, clotrimazole $75.37 \%$, ketoconazole $73.13 \%$, and itraconazole $69.40 \%$. Slightly resistance of antifungals was itraconazole, ketoconazole, clotrimazole, and voriconazole as shown in Table 3.

Table 3: Antifungal sensitivity profile of isolated Candida sp.

\begin{tabular}{ccc}
\hline Antifungals & $\begin{array}{c}\text { Sensitivity } \\
(\mathbf{\%})\end{array}$ & $\begin{array}{c}\text { Resistance } \\
(\mathbf{\%})\end{array}$ \\
\hline Nystatin & $127(94.8)$ & $7(5.2)$ \\
Fluconazole & $122(91.04)$ & $12(8.96)$ \\
Amphoteracin B & $119(88.8)$ & $15(11.2)$ \\
Voriconazole & $105(78.35)$ & $29(21.65)$ \\
Clotrimazole & $101(75.37)$ & $33(24.63)$ \\
Ketoconazole & $98(73.13)$ & $36(21.87)$ \\
Itraconazole & $93(69.40)$ & $41(29.60)$ \\
\hline
\end{tabular}

\section{DISCUSSION}

Vulvovaginal candidiasis represents one of the most frequent gynecological disorders caused by an overgrowth of Candida species in the mucosa membrane of the genital tract in the female ${ }^{14,27}$. In present results revealed that $62.5 \%$ of specimens were positive for Candida sp. growth in culture media while $38.5 \%$ of specimens were negative growth. The negative growth could be referred to as an infection caused by Trichmonasis vaginitis or bacteria vaginitis. In Sana'a, Yemen, Abdul-Aziz et al., ${ }^{18}$ revealed that $37.6 \%$ was positive for vaginal infections among reproductive-age women. Also, Al-mamari et al., ${ }^{28}$ in Sana'a, reported that $94 \%$ of vaginal samples of patients were positive growth for vulvovaginal candidiasis. In the current study, the women coming from rural areas had a higher rate $(65 \%)$ of vaginitis than patients from the urban area. This finding in disagreement with Abdul-Aziz et al., ${ }^{20}$ who revealed that $88.44 \%$ of vaginitis was among reproductivewomen residents in an urban area. The high occurrence of communicable vaginitis among rural women frequently refers to poor situations of healthcare, absence of health education, lower-income, and difficulty in medical treatment in time ${ }^{29}$. However, the education status plays a significant role in contributing to the improvement of personal hygiene which lacks in the rural area and that may explain the variance in the frequency of infection between the urban area and rural area ${ }^{14}$. The results regarding age group showed that the higher rate of Candida species infection was most frequently noticed among the age of 28-37 years and this finding was similar to a study by Al-Karim et al., ${ }^{30}$ in Syria. A similar study in Ethiopia by Bitew and Abebaw $^{14}$ recorded that the highest rate of vulvovaginal candidiasis was among age groups of 22-44 years. The current study found that 96 (71.64\%) of cases were reported as the first time infected with vulvovaginal candidiasis, while $38(28.36 \%)$ of cases were recorded as the recurrent vulvovaginal candidiasis. Most cases in the present work didn't have 
immunological diseases, so the first time exposure was highest and this finding was consistent with Sobel, ${ }^{31}$ in Nigeria. C. albicans is normal in a small amount that lives in the mucous membranes lining the genitals. It is the most responsible for vaginal candidiasis infection when occur disrupted in a healthy balance of microorganisms through pregnancy or medication. The high level of estrogen in the body during pregnancy can upset the healthy balance of microorganisms and increase the likelihood of developing a vaginal infection by Candida species. Also, various medications such as steroids, antibiotics, hormone therapy, chemotherapy, and radiotherapy can increase the risk too. Additional factors, such as stress, genitals washing with soap, wearing synthetic and tight clothes, sweating and using panty liners or sanitary pads. The present investigation reported that the $C$. albicans was the most isolated of Candida species with $61.2 \%$ from pregnant women suffering from vaginal candidiasis symptoms and this result is consistent with the report of Al-mamari et al., ${ }^{28}$ who found that the $65.95 \%$ of isolated Candida species was $C$. albicans. Another study by Omar et al., ${ }^{35}$ in Egypt showed that $C$. albicans was the highest $(78.3 \%)$ isolated species from infected women by vaginitis. In the last three decades, it has been observed that there was an increase in the percentage of vaginitis caused by species of Candida non-albicans. The present work revealed an increase in the frequency of non-albicans species considers as potential causes of vulvovaginal candidiasis. It was found that C. tropicalis (1.64\%), C. glabrata (11.19\%), and C. Kefyr $(5.97 \%)$ were recorded in this study. This finding was supported by a similar study by Babin et $a l .,{ }^{34}$ in Iran. The results of antifungal susceptibility, it was reported that all isolates were susceptible to tested antifungals. The highest sensitivity of antifungals against isolated Candida species was nystatin (94.8), fluconazole (91.04\%), amphotericin B (88.8\%), voriconazole $(78.35 \%)$, clotrimazole $(75.37 \%)$, ketoconazole (73.13\%), and itraconazole (69.40\%). Whereas slight resistance of antifungals was itraconazole, ketoconazole, clotrimazole, and voriconazole as reported against isolated Candida species. These findings are in agreement with the work of researchers that observed that most isolated Candida species were susceptible to tested antifungals ${ }^{28,35,36,37}$.

\section{CONCLUSION}

It can be concluded that vulvovaginal candidiasis is very common among pregnant women, and the tested anti-fungal agents continue to be effective against all isolates of Candida species. In contrast, there was a slight increase in resistance against itraconazole, ketoconazole, clotrimazole, and voriconazole which raises concern about a rise in Candida species that are resistant to these drugs.

\section{AUTHOR'S CONTRIBUTION}

The manuscript was carried out, written, and approved in collaboration with all authors.

\section{ACKNOWLEDGEMENTS}

The authors extend their thanks and appreciation to the Al-Razi University, Yemen to provide necessary facilities for this work.

\section{CONFLICT OF INTEREST}

No conflict of interest associated with this work.

\section{REFERENCES}

1. Achkar JM, Fries BC. Candida infections of the genitourinary tract. Clin Microbial Rev 2010; 253-273. https://doi.org/10.1128/CMR.00076-09

2. Eiderbrant K. Development of quantitative PCR methods for diagnosis of bacterial vaginosis and vaginal yeast infection. M.Sc. Thesis, Linkopings University, Linkoping, Sweden 2010; 25-114.

3. Ishida K, Ueda-Yamaguchi M, Yamada-Ogatta S, UedaNakamura T, Svidizinski T, Nakamura C. Characterization of Candida spp. isolated from vaginal fluid: Identification, antifungal susceptibility, and virulence profile. Acta Scientiarum2013; 35(1): 1-8. https://doi.org/10.4025/actascihealthsci.v35i1.13557

4. Corsello S, Spinillo A, Osnengo G, Pena C, Guaschino S, Beltrame A. An epidemiological survey of vulvovaginal candidiasis in Italy. Eur J Obstet Gynecol Reprod Biol 2003; 110:66-72. https://doi.org/10.1016/s0301-2115(03)00096-4

5. Grigoriou O, Baka S, Makrakis E, Hassiakos D, Kapparos G, Kouskouni E. Prevalence of clinical vaginal candidiasis in a University Hospital and possible risk factors. Eur J Obstet Gynecol Reprod Biol 2006; 126(1):121-125. https://doi.org/10.1016/j.ejogrb.2005.09.015

6. Das-Neves J, Pinto E, Teixeira B, Dias G, Rocha P, Cunha T. Local treatment of vulvovaginal candidosis: General and practical considerations. Drugs 2008; 68 (13): $1787-1802$.

https://doi.org/10.2165/00003495-200868130-00002

7. Eschenbach DA. Chronic vulvovaginal candidiasis. N Engl J Med 2004; 351:851-852. https://doi.org/10.1056/NEJMp048152

8. Morreira D, Paula CR. Vulvovaginal candidiasis. Int J Gynaecol Obstet 2006; 92: 266-267. https://doi.org/10.1016/j.ijgo.2005.12.007

9. Deoruhkar SC, Saini S. Vulvovaginal candidiasis due to non-albicans Candida: Its species distribution and antifungal susceptibility profile. Int J Curr Microbial App Sci 2013; 2(12): 323- 328.

10. Ben-Haroush A, Yogev Y, Kaplan B. The importance of diagnostic work-up in the management of candidal vulvovaginitis: a prospective study. Clin Exp Ob stet Gynecol 2004; 31:113- 116. PMID: 15266763

11. Boselli F, Chiossi G, Garutti P, Matteelli A, Montagna MT, Spinillo A. Preliminary results of the Italian epidemiological study on vulvovaginitis. Minerva Ginecol 2004; 56:149-153. PMID: 15258544

12. Babic M, Dukie M. Candida albicans and non-albicans species as etiological agent of vaginitis in pregnant and non-pregnant women. Bosn J Basic Med Sci 2010; 10 (1):89-97. https://doi.org/10.17305/bjbms.2010.2744

13. Ameri S, Falahati M, Kordbache P, Zaini F, Rahimi P. Activities of fluconazole in combination with terbinafine against non-albicans Candida species isolated from the patients with recurrent vulvovaginal candidiasis in comparison with ciclopirox olamine. Hormozgan Med J 2015; 18 (6): 516-521.

14. Bitew A, Abebaw Y. Vulvovaginal candidiasis: species distribution of Candida and their antifungal susceptibility pattern. BMC Women's Health 2018; 18:94. https://doi.org/10.1186/s12905-018-0607-z

15. Richter SS, Galask RP, Messer SA, Hollis RJ, Diekema DJ, Pfaller MA. Antifungal susceptibilities of Candida 
species causing vulvovaginitis and epidemiology of recurrent cases. J Clin Microbiol 2005; 43, 2155-2162. https://doi.org/10.1128/JCM.43.5.2155-2162.2005

16. AL-Haik WM, Al-Haddad AM. Bacterial vaginosis among pregnant women in Hadhramout-Yemen. Alandalus J Appl Sci 2017; 7(16):23-33.

17. Al-Kebsi AM, Othman AM, Al-Kasem MAA, Madar EM, Al-Shamahy HA, Al-Gaffari KM, Daname SMN, Motareb FL. Oral C. albicans colonization and noncandida albicans candida colonization among University students, Yemen. Universal J Pharm Res 2017; 2(5): 5-9. http://doi.org/10.22270/ujpr.v2i5.R2

18. Shoga Al-deen HM, Ahmed Ali O, Al-Shamahy HA, Al-Shami IZ, Saleh AL-amri MA, Al-labani MAC (2020) Oral Candida albicans colonization rate in fixed orthodontics patients. Universal J Pharm Res 2020; 5(2):1-5. https://doi.org/10.22270/ujpr.v5i2.380

19. Al-Haddad KA, Al-dossary OAE, Al-Shamahy HA. Prevalence and associated factors of oral non-Candida albicans Candida carriage in denture wearers in Sana'a city-Yemen. Universal J Pharm Res 2018; 3(4): 7-11. https://doi.org/10.22270/ujpr.v3i4.176

20. Maha AA, Mahdy AK, Ghani RA, et al. Bacterial vaginosis, vulvovaginal candidiasis and trichomonal vaginitis among reproductive-aged women seeking primary healthcare in Sana'a city, Yemen. BMC Infectious Diseases. 2019; 19:879-889. https://doi.org/10.1186/s12879-019-4549-3

21. Narkwa W. Antifungal susceptibility of Candida species and Cryptococcus neoformans isolated from patients at the Komfo Anokye Teaching Hospital in Kwnasi. M.Sc. Thesis, Kwame Nkrumah University of Science and Technology, Kumasi, Ghana. 2010

22. Lennox JA, Abbey SD, Udiba D, Mboto CI, Ikpoh IS, Akubuenyi FC. Prevalence of vaginitis and vaginosis among University of Calabar female students. J Public Health Epid 2013; 5(4): 167-172.

23. Rohde B, Hartmann G, Haude D, Kessieler HG, Langen ML. Introducing mycology by examples. Presented by Schering Aktiengesellschaft. Hamburg 1980; 35-98.

24. Isibor JO, Eghubare AE, Omoregie R. Germ tube formation in Candida albicans. Shiraze Med J 2005; 6 (1 and 2).

25. Jayalakshmi L, Kumari GR, Samson SH. Isolation, speciation and antifungal susceptibility testing of Candida from clinical specimens at a tertiary care hospital. J App Med Sci 2014; 2(6):3193-3198.

26. Clinical and Laboratory Standards Institute (CLSI). Performance Standards for Antimicrobial Disk Susceptibility Tests; Approved Standard. Twentysixth editions 2016 ; 58-116.
27. Rajkumar R, Radhakrishnan S, Seenivasan C, Kannan S. Culture and identification of Candida albicans from vaginal ulcer and separation of Enolase on SDS -PAGE. lnte J Bio 2010; 2(1): 84-93.

28. Al-mamari A, Al-buryhi M, Al-heggami AM, Al-hag S. Identify and sensitivity to antifungal drugs of Candida species causing vaginitis isolated from vulvovaginal infected patients in Sana'a city. Der Pharma Chemica, 2014; 6(1):336-342.

29. Abbas AM, Shaaban OM, Badran SM, Shaltout AS, Nasr A, Abdullah SA. Risk factors and health hazards of vaginal infections in upper Egypt: A cross sectional study. Thai J Obstet Gynecol 2016; 30: 50-6. https://doi.org/10.14456/tjog.2016.14

30. Al-Karim M, Maarouf M, Chahine E. The role of personal and medical factors and general state in fungal vaginitis in Syrian women. J Damascus Univ Health Scien 2007; 23(1): 239-249.

31. Sobel JD. Vulvovaginal candidosis. Lancet 2007; 369: 1961-1971. https://doi.org/10.1016/S0140-6736(07)60917-9

32. Ferrer J. Vaginal candidosis: epidemiological and etiological factors. Int J Gynecol Obst 2000; 71:S21S27.

https://doi.org/10.1016/s0020-7292(00)00350-7

33. Grigoriou O, Baka S, Makrakis E, et al. (2006) Prevalence of clinical vaginal candidiasis in a university hospital and possible risk factors. European J Obst Gynecol Reprod Biol 126(1):121-125. https://doi.org/10.1016/j.ejogrb.2005.09.015

34. Babin D, Kotigadde S, Rao P, Rao T. Clinicomycological profile of vaginal candidiasis in a Tertiary Care Hospital in Kerala. Int J Res Bio Sci 2013; 3(1):5559.

35. Omar MS, Abbas AM, Moharram AM, Farhan MM, Hassanen IH. Does vaginal douching affect the type of candidal vulvovaginal infection? Myd Mycol 2015; 53(8):817-827. https://doi.org/10.1093/mmy/myv042

36. Abruquah HH. Prevalence and antifungal susceptibility of Candida species isolated from women attending Gynaecological clinic in Kumasi, Ghana. Ournal Sci Tech 2012; 32 (2): 39-45. https://doi.org/10.4314/just.v32i2.6

37. Khan M, Ahmed J, Gul A, Ikram A, Lalan KF. Antifungal susceptibility testing of vulvovaginal Candida species among women attending antenatal clinic in tertiary care hospitals of Peshawar. Infection Drug Resist 2018; 11: 447-456.

http://dx.doi.org/10.2147/IDR.S153116 